\title{
Uptake, Translocation and Metabolism of the Herbicide Molinate in Tobacco and Rice
}

\author{
Yar-Ning Hsieh, ${ }^{1}$ Li-Fei $\mathrm{Liu}^{2} \&$ Yei-Shung Wang ${ }^{1 *}$ \\ ${ }^{1}$ Department of Agricultural Chemistry, National Taiwan University, Taipei, Taiwan \\ 2 Department of Agronomy, National Taiwan University, Taipei, Taiwan \\ (Received 19 August 1997; revised version received 5 January 1998; accepted 30 January 1998)
}

\begin{abstract}
Molinate, a selective herbicide, is used for the control of annual and perennial weeds in rice paddy fields. This study was designed to assess the basis of the selective action of molinate between a susceptible broadleaf crop, tobacco, and a resistant graminaceous plant, rice. Experiments were conducted comparing plant growth under different concentrations of molinate, determining the absorption and translocation of the herbicide in the plant and identifying the metabolites in suspension cells. Rice showed greater tolerance to molinate than tobacco. Leaves of tobacco showed retarded and distorted growth at $10 \mathrm{mg} \mathrm{liter}^{-1}$ of molinate 14 days after treatment, but rice leaves were unaffected at this concentration. Higher concentrations of molinate accumulating in the root of tobacco seedlings may inhibit root development and represent a significant factor in the herbicide's selective action. Seven and eight metabolites were found in tobacco and rice cells, respectively, with molinate sulfoxide and molinate sulfone present in both species. (C) $1998 \mathrm{SCI}$
\end{abstract}

Pestic. Sci., 53, 149-154 (1998)

Key words: molinate; uptake; translocation; metabolism; tobacco; rice

\section{INTRODUCTION}

Molinate ( $S$-ethyl perhydroazepine-1-carbothioate) is extensively used as a selective herbicide to control germinating broad-leaves and grassy weeds in rice paddy fields. Molinate is applied after water seeded or drilled rice is flooded and after the aquatic weed has emerged about $5-10 \mathrm{~cm}$ from the soil, and is at least two-thirds submerged by the water. Rates of application are from 2.2 to $3.4 \mathrm{~kg} \mathrm{ha}^{-1}$. A number of studies have been published on the fate and selectivity of molinate. Molinate controls barnyardgrass (Echinochloa crus-galli (L.) Beauvois) in paddy rice fields, and Chem et al. ${ }^{1}$ reported that barnyardgrass absorbed more molinate than did rice. Imai and Kuwatsuka ${ }^{2}$ found similar results, deduc-

\footnotetext{
* To whom correspondence should be addressed. Contract/grant sponsor: Council of Agriculture of the Republic of China.

Contract/grant number: 84-Science-2.4-Food-37(1)-01.
}

ing that molinate only moved acropetally in rice plants, but both acropetally and basipetally in barnyardgrass when applied to the basal part of the shoots, although the molinate showed whole-plant systemicity in both plants when applied to the roots. In a study on effect of thiocarbamate herbicides on fatty acid synthesis by potato, Bolton and Harwood ${ }^{3}$ found that thiocarbamates reduce the amount of surface lipid of plants. Evidence suggesting that thiocarbamates inhibit one or more acyl-CoA elongases is largely indirect. ${ }^{4}$ Imai and Kuwatsuka $^{5-8}$ studied the degradation of this herbicide in soil and its metabolism by soil microorganisms. Soderquist et al..$^{9}$ reported that photodecomposition products of molinate were present in field water, and that volatilization of molinate from water was the primary mode of dissipation in the environment. Ross and Sava $^{10}$ determined atmospheric residues at $48 \mathrm{~cm}$ above the water surface, finding that the maximum molinate concentration was $48 \mu \mathrm{g} \mathrm{m}^{-3}$ on the day of application of $3 \cdot 10 \mathrm{~kg} \mathrm{ha}^{-1}$ to rice fields. In a study in rice 
by Imai and Kuwatsuka, ${ }^{11} 21 \%$ of the total molinate applied was detected in the soil and $1.6 \%$ in the rice plants at harvest, and of the molinate residues found in the rice plants, about $96 \%$ was in straw and $4 \%$ in the grains.

The present study was carried out to clarify the absorption and translocation of molinate in plants of tobacco, a susceptible broad-leaf, and rice. The metabolism of molinate in suspension cells tissue culture of both plants was also determined.

\section{MATERIALS AND METHODS}

\subsection{Materials}

[Ethyl-1 $\left.-{ }^{14} \mathrm{C}\right]$ molinate was provided by Asahi Chemical Industry Co., Ltd, Japan, and had a specific activity of $107.3 \mathrm{MBq} \mathrm{mmol}{ }^{-1}$ and a radiochemical purity of greater than $99 \%$. Analytical grade molinate of greater than $99 \%$ purity was purchased from Riedel de Haen Co., Germany. Seeds of tobacco (Nicotiana tabacum L. cv. Wisconsin 38) and rice (Oryza sativa L. cv. Tainan 5) were provided by the Department of Botany and Department of Agronomy, National Taiwan University, respectively.

\subsection{Seedling preparation}

Seeds of tobacco were soaked in ethanol + water $(75+25$ by volume) for $1 \mathrm{~min}$ and sterilized with sodium hypochlorite solution $\left(10 \mathrm{~g} \mathrm{liter}^{-1}\right)$ for $15 \mathrm{~min}$. Heavy rice seeds were selected with sodium chloride solution $\left(50 \mathrm{~g} \mathrm{liter}^{-1} \text {; relative density } 1.05\right)^{12}$ and then surface sterilized for $2 \mathrm{~h}$ with sodium hypochlorite $(10 \mathrm{~g}$ liter ${ }^{-1}$ ), adding one drop of 'Tween'-20. After washing three times with deionized water, the tobacco seeds were germinated and grown in glass bottles containing MS agar medium ${ }^{13}(50 \mathrm{ml})$ for several weeks at $25^{\circ} \mathrm{C}$ under 3000 lux illumination $\left(16 \mathrm{~h} \mathrm{day}^{-1}\right)$, and the rice seeds were germinated on a stainless steel net laid on the upper surface of liquid in glass bottles containing MS liquid medium for one week. Shoot apices of tobacco plants were excised and transplanted every three to five weeks.

\subsection{Effect of molinate on growth of tobacco and rice plants}

Tobacco plants (two weeks after transplantation, $5 \mathrm{~cm}$ in height) and rice plants (one week after germination, $7 \mathrm{~cm}$ in height) were transferred to MS liquid medium (complemented with sucrose and vitamins) containing 0 , 1,10 and $100 \mathrm{mg} \mathrm{liter}{ }^{-1}$ of molinate, separately. After incubating for 14 days, gross effects or whole plant growth were noted. The experiment was performed in duplicate.

\subsection{Absorption and translocation of molinate by plants}

Rice seedlings and shoot apices from tobacco plants were removed and transferred to another glass bottle containing MS liquid medium $(30 \mathrm{ml})$ and glass beads. The plants were fixed with glass beads. After roots had developed (seven days), $\left[{ }^{14} \mathrm{C}\right]$ molinate $(0 \cdot 11 \mathrm{MBq})$ was added to the medium. After incubating for two and seven days, whole plants were washed with distilled water containing acetone $\left(1.0 \mathrm{ml}\right.$ liter $\left.^{-1}\right)$ and 'Tween'$20\left(1.0 \mathrm{ml} \mathrm{liter}^{-1}\right)$, fixed on a glass plate and then covered with X-ray film $(20 \times 25 \mathrm{~cm}$, Kodak X-Omat AR) at $-20^{\circ} \mathrm{C}$ for two months for autoradiography. The plant materials were then subjected to wet combustion and the radioactivity was quantified. The test was performed in duplicate. Detailed methods are described elsewhere. ${ }^{14}$

For a thorough understanding of the relationship between molinate concentration and plant absorption and translocation, an experiment was also performed by adding $2 \cdot 5,5 \cdot 0,7 \cdot 5$ or $10 \cdot 0 \mathrm{mg}$ liter ${ }^{-1}$ of $\left[{ }^{14} \mathrm{C}\right]$ molinate to the medium and determining the radioactivity in the shoot and root after incubation for two days. Each test was performed in duplicate.

\subsection{Suspension cultures of tobacco leaf cells and rice embryogenic cells}

For callus preparation, whole tobacco leaves from beneath the shoot apices were sliced into pieces of $1-2 \mathrm{~cm}$ in length, and placed on MS agar medium containing 2-(1-naphthyl)acetic acid (NAA; $1.0 \mathrm{mg} \mathrm{liter}^{-1}$ ) and 6-benzylaminopurine (BAP; $0.1 \mathrm{mg} \mathrm{liter}^{-1}$ ) for callus induction. Induced callus was suspended and dispersed in a MS liquid medium containing NAA, $(0.5 \mathrm{mg}$ liter $\left.^{-1}\right)$ and BAP, $\left(0 \cdot 1 \mathrm{mg} \operatorname{liter}^{-1}\right)$. The cultures were shaken at $100 \mathrm{rev} \min ^{-1}$ at $25^{\circ} \mathrm{C}$. Homogeneous suspensions were obtained by filtering with a $1-\mathrm{mm}$ filter net. Subculture was performed every two weeks.

Rice embryogenic calli obtained from cultured immature embryos of rice seed were transplanted and cultured in a 250-ml flask containing MS liquid medium $(50 \mathrm{ml})$ supplemented with $2,4-\mathrm{D}(10 \mu \mathrm{M})$ on a shaker (100 rev $\left.\mathrm{min}^{-1}\right)$. Homogeneous suspensions were obtained by filtering with a 1-mm filter net. Subculture was performed every seven days.

\subsection{Metabolism of molinate in tobacco and rice cell suspensions}

Metobolism of molinate in tobacco and rice was examined by culturing the cells in medium containing 
$\left[{ }^{14} \mathrm{C}\right]$ molinate $\left(10 \mathrm{mg}\right.$ liter $\left.^{-1}\right)$. In five $50 \mathrm{ml}$-flasks, $\left[{ }^{14} \mathrm{C}\right]$ molinate solution $(0.037 \mathrm{M} \mathrm{Bq})$ in ethanol was added to the suspension $(10 \mathrm{ml}$; approximate cell density $4 \times 10^{5} \mathrm{ml}^{-1}$ ) in each flask to give $10 \mathrm{mg}$ liter ${ }^{-1}$ concentration of molinate. The cells were shaken at $25^{\circ} \mathrm{C}$ under 3000 lux illumination and $50 \mathrm{rev} \mathrm{min}^{-1}$. After incubating for 3, 6, 12, 24 and $48 \mathrm{~h}$, one flask was taken and the suspension was centrifuged $(1000 \mathrm{~g}$, Sigma $2 \mathrm{~K}-1512139$ rotor) to sediment the cells. The cells were collected, washed with MS liquid medium $(5 \mathrm{ml})$ and again centrifuges. The percentage of radioactivity remaining in the culture medium was determined. Collected cells were added to $70 \%$ acetone $(10 \mathrm{ml})$, homogenized and extracted three times. The extracts were combined, diluted with water and then extracted with hexane three times. The procedure for determining molinate and its metabolites is shown in Fig. 1, a method used previously by Imai and Kuwatsuka. ${ }^{2}$ The radioactivity of the residues was determined by the wet combustion method. ${ }^{14}$ Metabolites were analyzed by co-chromatography with authentic standards. Hexane and ether extracts were concentrated and cochromatographed. Polar conjugates were hydrolysed with hydrochloric acid $(1 \mathrm{M})$ at $70^{\circ} \mathrm{C}$ for $2 \mathrm{~h}$.

The metabolites molinate sulfoxide [1-ethylsulfinylcarbonyl perhydroazepine] and molinate sulfone

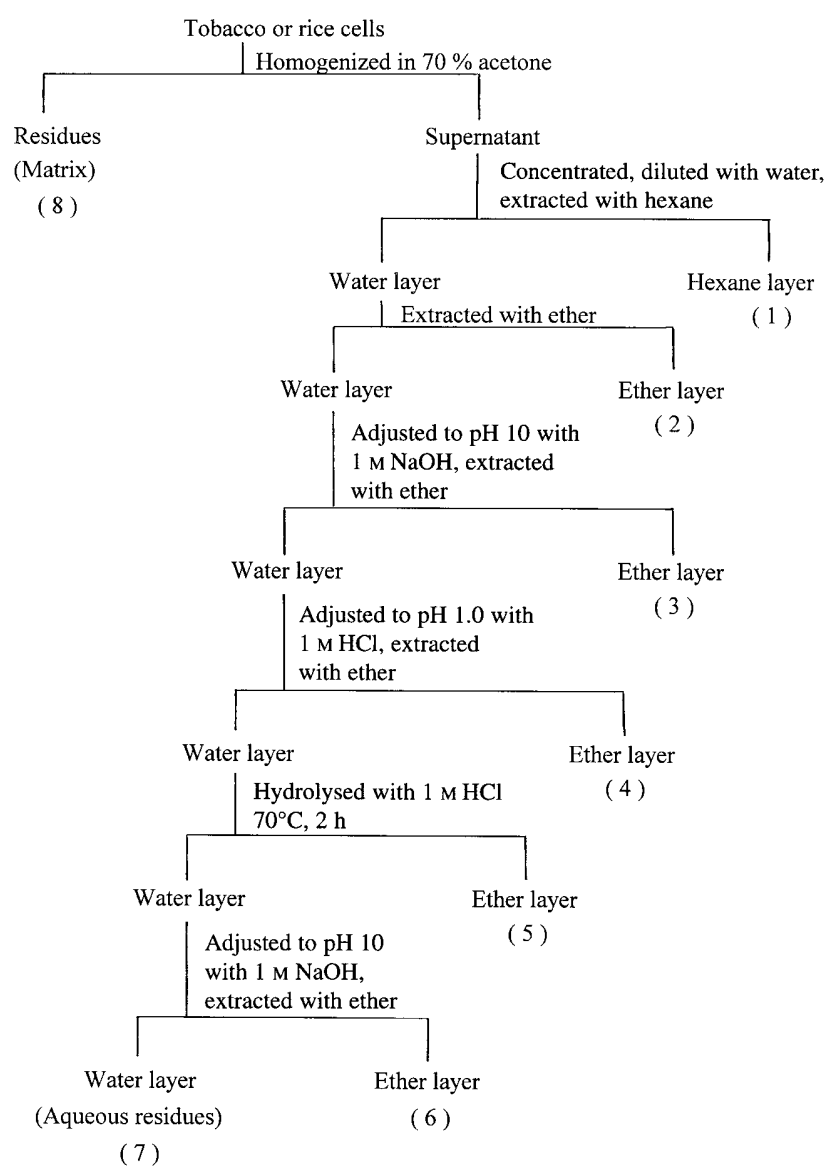

Fig. 1. Extraction of molinate and its metabolites from tobacco and rice cells. [1-ethylsulfonylcarbonyl perhydroazepine] were prepared by the method of Soderquist et al. ${ }^{9}$ and identified by GC-MS and FT-IR (Bio-red model FTS-7). GC-MS analysis was performed by using Shimadzu GC-14A interfaced to a QP1100EX mass detector equipped with a Supelco PTE 5 fused silica capillary column (30 $\mathrm{m} \times 0.25 \mathrm{~mm}$ ID, film thickness $0.25 \mu \mathrm{m})$. Helium was used as the carrier gas with a flow rate of $3 \mathrm{ml} \mathrm{min}{ }^{-1}$ with split ratio $1: 50$. The injection port temperature was $200^{\circ} \mathrm{C}$; interface was $250^{\circ} \mathrm{C}$; oven temperature was held at $100^{\circ} \mathrm{C}$ for $5 \mathrm{~min}$, then programmed to $250^{\circ} \mathrm{C}$ at $10^{\circ} \mathrm{C} \mathrm{min}^{-1}$, and maintained at the final temperature of $250^{\circ} \mathrm{C}$ for $20 \mathrm{~min}$. Following identification by GC-MS, the retention times were found to be $18.9 \mathrm{~min}$ (molinate sulfoxide) and $16.9 \mathrm{~min}$ (molinate sulfone), both compounds displaying base peak $m / e 126$ $\left(\mathrm{C}_{6} \mathrm{H}_{12} \mathrm{NCO}\right)$.

Thin layer chromatography was performed on silica gel $60 \mathrm{~F}_{254}$ (Merck 5715) using hexane + acetone $(1+1$ by volume) as developing solvent and metabolites were identified at $254 \mathrm{~nm}$ with a UV lamp. The $R_{\mathrm{f}}$ values of molinate, molinate sulfoxide and molinate sulfone were $0 \cdot 90,0.55$ and 0.83 , respectively.

\section{RESULTS AND DISCUSSION}

Effects of different concentrations of molinate on the growth of tobacco and rice plants were compared after incubation for 14 days. Growth of tobacco shoots was not affected by $1 \mathrm{mg} \mathrm{liter}^{-1}$ of molinate, but leaf distortion and growth inhibition were found at $10 \mathrm{mg} \mathrm{liter}^{-1}$. At a concentration of $100 \mathrm{mg} \mathrm{liter}{ }^{-1}$, the older leaves showed necrosis and a brownish colour. Growth of tobacco roots was slightly inhibited by $1 \mathrm{mg} \mathrm{liter}^{-1}$ of molinate, and when the concentration exceed $10 \mathrm{mg}$ liter ${ }^{-1}$, root development was greatly inhibited. The growth of rice plants was inhibited and the leaves become a brownish colour at a concentration of $100 \mathrm{mg}$ liter $^{-1}$. Rice plants showed more tolerance to molinate than tobacco. The lengths of shoots and roots of both species after treatment with different concentrations of molinate are shown in Table 1.

Autoradiograms (not shown) and tissue combustion of $\left[{ }^{14} \mathrm{C}\right]$ molinate-treated plants indicated that, in tobacco, more $\left[{ }^{14} \mathrm{C}\right]$ derived from molinate remained in the root than translocated to the shoot after two days incubation, but most of the radioactivity was translocated to the shoot at seven days, when expressed on a $\mathrm{dpm} \mathrm{g}^{-1}$ basis. By contrast, in rice radioactivity translocated more rapidly to the shoot at two days after incubation. Table 2 shows the plant distribution of $\left[{ }^{14} \mathrm{C}\right]$ derived from molinate. No obvious difference was found for total $\left[{ }^{14} \mathrm{C}\right]$ absorption between the two species; about $0.59 \%(0.17 \%$ in root and $0.42 \%$ in shoot) and $0.55 \%(0.2 \%$ in root and $0.35 \%$ in shoot $)$ of the total activity being absorbed by tobacco and rice, 
TABLE 1

Length of Tobacco and Rice Shoots and Roots after Treatment with Different Concentrations of Molinate

\begin{tabular}{|c|c|c|c|c|}
\hline \multirow{3}{*}{$\begin{array}{c}\text { Concentration } \\
\text { of molinate } \\
\left(\mathrm{mg} \mathrm{liter}^{-1}\right)\end{array}$} & \multicolumn{4}{|c|}{ Organ length $(\mathrm{cm})( \pm S D)$} \\
\hline & \multicolumn{2}{|c|}{ Tobacco } & \multicolumn{2}{|c|}{ Rice } \\
\hline & Shoot & Root & Shoot & Root \\
\hline Control & $4 \cdot 03( \pm 0 \cdot 40)$ & $6 \cdot 38( \pm 0 \cdot 26)$ & $17 \cdot 00( \pm 0 \cdot 90)$ & $5 \cdot 27( \pm 0 \cdot 25)$ \\
\hline 1 & $5 \cdot 03( \pm 0 \cdot 20)$ & $5 \cdot 44( \pm 0 \cdot 37)$ & $19 \cdot 01( \pm 1 \cdot 22)$ & $6.02( \pm 0.95)$ \\
\hline 10 & $3 \cdot 39( \pm 0 \cdot 23)$ & $2 \cdot 20( \pm 1 \cdot 35)$ & $18 \cdot 44( \pm 0 \cdot 14)$ & $5 \cdot 54( \pm 0 \cdot 27)$ \\
\hline 100 & $1.68( \pm 0.06)$ & 0 & $6 \cdot 80( \pm 0 \cdot 80)$ & $4 \cdot 06( \pm 0 \cdot 40)$ \\
\hline
\end{tabular}

respectively, after incubation for seven days. Chem et al. ${ }^{1}$ and Imai and Kuwatsuka ${ }^{2}$ had noted that E. crusgalli absorbed more molinate and rice absorbed relatively less molinate and therefore this may be the reason for molinate's selectivity. The higher level of radioactivity in the roots of tobacco compared with those of rice may indicate that a critical level of molinate or its metabolites in tobacco roots may be a factor in the selective activity of the herbicide. Figure 2 clarifies this point and shows the relationship between $\left[{ }^{14} \mathrm{C}\right]$ molinate concentration and accumulation by tobacco and rice plants when incubated for two days. The results showed that the higher the concentration of molinate present in culture solution, the more molinate was absorbed by both species. However, most of the molinate absorbed was translocated to the shoot in rice plants and only a small amount remained in root, regardless of the concentration. On the other hand, most of molinate absorbed by tobacco accumulated in the root, only a small amount being translocated to the shoot.

After exposing cell suspensions to $\left[{ }^{14} \mathrm{C}\right]$ molinate for two days, the herbicide and its metabolites were determined. Table 3 lists the percentages of radioactivity distribution in different extraction fractions after different incubation periods. In rice cells, more than $60 \%$ of the radioactivity derived from $\left[{ }^{14} \mathrm{C}\right]$ molinate was found in the aqueous residue fraction after $48 \mathrm{~h}$, implying conversion to polar metabolites. Rice cells were able to metabolize molinate to polar metabolites more rapidly than tobacco cells. The relatively non-polar metabolites (hexane fraction) accounted for $15-30 \%$ in rice cells and were lower than that in tobacco cells. After acid hydro-

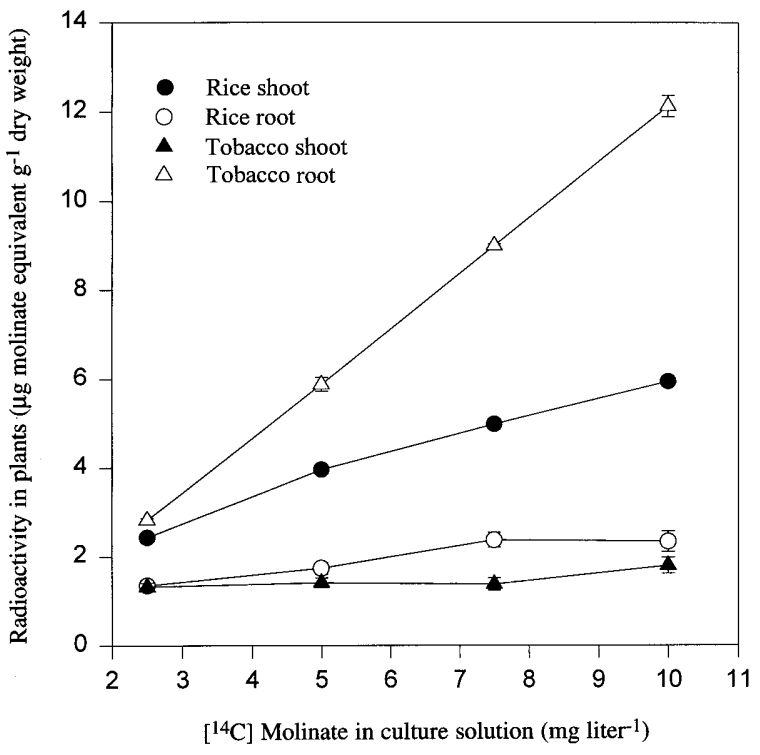

Fig. 2. Relationship between $\left[{ }^{14} \mathrm{C}\right]$ molinate concentration and accumulation by tobacco and rice plants after two days.

TABLE 2

Absorption and Translocation of Radioactivity Derived from $\left[{ }^{14} \mathrm{C}\right]$ molinate in Tobacco and Rice Plants

\begin{tabular}{|c|c|c|c|c|c|}
\hline & \multirow{2}{*}{$\begin{array}{l}\text { Incubation } \\
\quad \text { (days) }\end{array}$} & \multicolumn{2}{|c|}{ Tobacco } & \multicolumn{2}{|c|}{ Rice } \\
\hline & & Root & Shoot & Root & Shoot \\
\hline Radioactivity & 2 & $2664( \pm 51)$ & $2758( \pm 37)$ & $3605( \pm 33)$ & $3912( \pm 32)$ \\
\hline in plant (dpm) & 7 & $11040( \pm 229)$ & $28026( \pm 186)$ & $12950( \pm 59)$ & $23364( \pm 147)$ \\
\hline Plant weight & 2 & $0.01( \pm 0.000)$ & $0.07( \pm 0.007)$ & $0.07( \pm 0.007)$ & $0.03( \pm 0.000)$ \\
\hline$(\mathrm{dry}, \mathrm{g})$ & 7 & $0.02( \pm 0.000)$ & $0 \cdot 18( \pm 0.007)$ & $0.05( \pm 0.000)$ & $0.06( \pm 0.007)$ \\
\hline \multirow[t]{2}{*}{$\mathrm{dpm} \mathrm{g}^{-1}$} & 2 & $266400( \pm 5100)$ & $39400( \pm 4000)$ & $51500( \pm 5200)$ & $130400( \pm 1100)$ \\
\hline & 7 & $552000( \pm 11400)$ & $155700( \pm 6100)$ & $259000( \pm 1200)$ & $339400( \pm 46700)$ \\
\hline${ }^{14} \mathrm{C}$ & 2 & $0.04( \pm 0.001)$ & $0.04( \pm 0.001)$ & $0.05( \pm 0.001)$ & $0.06( \pm 0.000)$ \\
\hline absorbed $(\%)$ & 7 & $0.17( \pm 0.003)$ & $0.42( \pm 0.003)$ & $0.20( \pm 0.001)$ & $0.35( \pm 0.002)$ \\
\hline
\end{tabular}


TABLE 3

Distribution of Radioactivity in Different Extract Fractions when Tobacco and Rice Suspension Cells Were Incubated in

$\left[{ }^{14} \mathrm{C}\right]$ Molinate for Different Periods

\begin{tabular}{|c|c|c|c|c|c|c|c|c|c|}
\hline \multirow{4}{*}{$\begin{array}{c}\text { Incubation } \\
\text { time } \\
(h)\end{array}$} & \multicolumn{8}{|c|}{ Radioactivity recovered $(\%)$} & \multirow{4}{*}{$\begin{array}{c}\text { Total } \\
\text { radioactivity } \\
(\text { dpm })\end{array}$} \\
\hline & \multicolumn{5}{|c|}{$\begin{array}{l}\text { Supernatant following extraction in } \\
70 \% \text { acetone }\end{array}$} & \multicolumn{3}{|c|}{ After hydrolysis } & \\
\hline & \multirow{2}{*}{$\begin{array}{l}\text { Matrix } \\
\text { residues } \\
\qquad(8)^{a}\end{array}$} & \multirow{2}{*}{$\begin{array}{l}\text { Hexane } \\
\text { extract } \\
(1)\end{array}$} & \multicolumn{3}{|c|}{ Ether extract } & \multicolumn{2}{|c|}{ Ether extract } & \multirow{2}{*}{$\begin{array}{l}\text { Aqueous } \\
\text { residue } \\
\quad(7)\end{array}$} & \\
\hline & & & $\begin{array}{l}\text { Neutral } \\
\text { (2) }\end{array}$ & $\begin{array}{c}\text { Basic } \\
\text { (3) }\end{array}$ & $\begin{array}{c}\text { Acidic } \\
\text { (4) }\end{array}$ & $\begin{array}{c}\text { Acidic } \\
\quad(5)\end{array}$ & $\begin{array}{l}\text { Basic } \\
(6)\end{array}$ & & \\
\hline \multicolumn{10}{|l|}{ Tobacco } \\
\hline 3 & $0 \cdot 3$ & $45 \cdot 1$ & $6 \cdot 4$ & $5 \cdot 1$ & $2 \cdot 5$ & $1 \cdot 2$ & $0 \cdot 8$ & $38 \cdot 5$ & 174200 \\
\hline 6 & $0 \cdot 2$ & $27 \cdot 9$ & $9 \cdot 0$ & $5 \cdot 9$ & $3 \cdot 3$ & $1 \cdot 7$ & $1 \cdot 0$ & $51 \cdot 0$ & 157400 \\
\hline 12 & $0 \cdot 3$ & $23 \cdot 4$ & $9 \cdot 6$ & $6 \cdot 0$ & $3 \cdot 4$ & $1 \cdot 7$ & $1 \cdot 6$ & $53 \cdot 9$ & 140300 \\
\hline 24 & $0 \cdot 1$ & $40 \cdot 0$ & $4 \cdot 8$ & $3 \cdot 0$ & $2 \cdot 0$ & $2 \cdot 0$ & $0 \cdot 8$ & $47 \cdot 2$ & 220700 \\
\hline 48 & $0 \cdot 2$ & $29 \cdot 2$ & $7 \cdot 0$ & $5 \cdot 6$ & $2 \cdot 6$ & $1 \cdot 4$ & $1 \cdot 3$ & $52 \cdot 6$ & 181100 \\
\hline \multicolumn{10}{|l|}{ Rice } \\
\hline 3 & $0 \cdot 2$ & $26 \cdot 8$ & $20 \cdot 7$ & $7 \cdot 4$ & $2 \cdot 7$ & $1 \cdot 0$ & $1 \cdot 5$ & $39 \cdot 6$ & 155500 \\
\hline 6 & $0 \cdot 2$ & $30 \cdot 4$ & $18 \cdot 0$ & $4 \cdot 5$ & $2 \cdot 3$ & $0 \cdot 9$ & $0 \cdot 8$ & $42 \cdot 9$ & 179600 \\
\hline 12 & $0 \cdot 2$ & $25 \cdot 4$ & $14 \cdot 1$ & $4 \cdot 2$ & $2 \cdot 4$ & $1 \cdot 1$ & $1 \cdot 3$ & $51 \cdot 2$ & 173600 \\
\hline 24 & $0 \cdot 4$ & $20 \cdot 4$ & $10 \cdot 5$ & $4 \cdot 2$ & $3 \cdot 2$ & $1 \cdot 1$ & $1 \cdot 7$ & $58 \cdot 4$ & 148200 \\
\hline 48 & $0 \cdot 2$ & $15 \cdot 0$ & $10 \cdot 4$ & $7 \cdot 9$ & $3 \cdot 6$ & $1 \cdot 2$ & $1 \cdot 6$ & $60 \cdot 1$ & 184700 \\
\hline
\end{tabular}

${ }^{a}$ The number corresponds to the fractions in Fig. 1.

lysis, ${ }^{14} \mathrm{C}$-compounds in the ether extracts showed no significant different between tobacco and rice cell, the sum of residues in the acidic and basic ether extracts totalling 1.7 to $3.3 \%$ of total radioactivity found in the cell. These results imply that only small amounts of $\left[{ }^{14} \mathrm{C}\right]$ molinate were conjugated as glycosides or other complexes.

When the $70 \%$ acetone extract was separated by thin layer chromatography, in addition to the parent molinate, eight (in tobacco) and 10 (in rice) spots were observed on chromatographic plates. Most of these metabolites were found in cells of both species, such as molinate sulfone, $\left(R_{\mathrm{f}} 0.83\right)$, molinate sulfoxide, $\left(R_{\mathrm{f}} 0.55\right)$ and several unknown compounds with $R_{\mathrm{f}}$ values $0 \cdot 86$, $0.79,0.72,0.68$ and at the origin. However, tobacco cells also formed unknown compounds with $R_{\mathrm{f}}$ values 0.76 and 0.03 , and in rice cells, additional metabolites were found at $R_{\mathrm{f}} 0.95,0.37$ and 0.18 . There are therefore significant differences in the metabolites produced by rice and tobacco cells. The aqueous layers (after acid

TABLE 4

Change in Amounts of $\left[{ }^{14} \mathrm{C}\right]$ Molinate and Its Metabolites in Tobacco and Rice Cells and in Culture Medium with Incubation Time

\begin{tabular}{|c|c|c|c|c|c|c|c|c|c|c|}
\hline \multirow{4}{*}{$\begin{array}{c}\text { Incubation } \\
\text { time } \\
(h)\end{array}$} & \multicolumn{10}{|c|}{ Amount found $(\%)$} \\
\hline & \multicolumn{4}{|c|}{ Tobacco ${ }^{a}$} & \multicolumn{4}{|c|}{ Rice $^{a}$} & \multirow{2}{*}{\multicolumn{2}{|c|}{$\begin{array}{l}\text { In culture } \\
\text { medium }^{b}\end{array}$}} \\
\hline & \multirow[b]{2}{*}{ Molinate } & \multicolumn{3}{|c|}{ Metabolites $^{c}$} & \multirow[b]{2}{*}{ Molinate } & \multicolumn{3}{|c|}{ Metabolites $^{c}$} & & \\
\hline & & MSO & $\mathrm{MSO}_{2}$ & Others & & MSO & $\mathrm{MSO}_{2}$ & Others & Tobacco & Rice \\
\hline 3 & $23 \cdot 0$ & $1 \cdot 6$ & $3 \cdot 0$ & $72 \cdot 4$ & $18 \cdot 6$ & $2 \cdot 3$ & $3 \cdot 8$ & $75 \cdot 3$ & $81 \cdot 8$ & $83 \cdot 9$ \\
\hline 6 & $11 \cdot 8$ & $1 \cdot 5$ & $3 \cdot 0$ & $83 \cdot 7$ & $14 \cdot 0$ & $1 \cdot 8$ & $3 \cdot 5$ & $80 \cdot 7$ & $85 \cdot 7$ & $83 \cdot 0$ \\
\hline 12 & $10 \cdot 8$ & $2 \cdot 0$ & $3 \cdot 0$ & $84 \cdot 2$ & $9 \cdot 3$ & $2 \cdot 0$ & $3 \cdot 4$ & $85 \cdot 3$ & $86 \cdot 5$ & $83 \cdot 2$ \\
\hline 24 & $9 \cdot 7$ & $1 \cdot 3$ & $1 \cdot 7$ & $87 \cdot 3$ & $10 \cdot 3$ & $2 \cdot 6$ & $2 \cdot 8$ & $84 \cdot 3$ & $81 \cdot 0$ & $85 \cdot 9$ \\
\hline 48 & $6 \cdot 8$ & $1 \cdot 4$ & $2 \cdot 8$ & $89 \cdot 0$ & $6 \cdot 5$ & $1 \cdot 3$ & $2 \cdot 0$ & $90 \cdot 2$ & $84 \cdot 2$ & $85 \cdot 9$ \\
\hline
\end{tabular}

$a \%$ of total radioactivity in cells.

$b \%$ of total radioactivity applied.

${ }^{c}$ MSO: molinate sulfoxide; $\mathrm{MSO}_{2}$ : molinate sulfone. 
analysis, fraction 7 in Fig. 1) contained only two spots, an unknown compound at $R_{\mathrm{f}} 0.72$ and activity retained at the origin.

The amounts of molinate and the major metabolites, the sulfoxide and the sulfone of molinate, in cells of both species were determined (Table 4). The percentages of the radioactivity for the other metabolites in the cell and in the cell-culture fluid were determined separately and are shown in Table 4 . Several papers ${ }^{15-17}$ have reported that thiocarbamate herbicides must be metabolized in the plant to thiocarbamate sulfoxides to exhibit herbicidal activity, but this is disputed by Jablonkai and Hatzios. ${ }^{18}$ Imai and Kuwatsuka ${ }^{2}$ have proposed a metabolic pathway for molinate degradation in plants. They reported that molinate initially formed molinate sulfoxide, and this was then conjugated with glutathione or oxidized to molinate sulfone. In this study the differences in metabolism of molinate between rice and tobacco are minimal and do not appear to be a significant factor in selectivity. However, studies on metabolism in whole plants are required to clarify the role of metabolism further.

\section{ACKNOWLEDGEMENTS}

The authors wish to express their thanks to Asahi Chemical Industry Co., Ltd, Japan, for providing ${ }^{14} \mathrm{C}$ labelled molinate. This research was supported by the Council of Agriculture of the Republic of China. Grant No.: 84-Science-2.4-Food-37(1)-01.

\section{REFERENCES}

1. Chem, T. M., Seaman, D. E. \& Ashton, F. M., Herbicidal action of molinate in barnyardgrass and rice. Weed Sci., 16 (1968) 28-31.

2. Imai, Y. \& Kuwatsuka, S., Uptake, translocation and metabolic fate of the herbicide molinate in plants. Nihon Noyaku Gakkaishi (J. Pestic. Sci.), 9 (1984) 79-90.

3. Bolton, P. \& Harwood, J. L., Effect of thiocarbamate herbicides on fatty acid synthesis by potato. Phytochemistry, 15 (1976) 1507-9.
4. Gonwald, J. W., Lipid biosynthesis inhibitors. Weed Sci., 39 (1991) 435-49.

5. Imai, Y. \& Kuwatsuka, S., Degradation of the herbicide molinate in soils. Nihon Noyaku Gakkaishi (J. Pestic. Sci.), 7 (1982) 487-97.

6. Imai, Y. \& Kuwatsuka, S., Characteristics of microflora degrading the herbicide molinate in soil. Nihon Noyaku Gakkaishi (J. Pestic. Sci.), 11 (1986) 57-63.

7. Imai, Y. \& Kuwatsuka, S., The mode of metabolism of the herbicide molinate by four strains of microorganisms isolated from soil. Nihon Noyaku Gakkaishi (J. Pestic. Sci.), 11 (1986) 111-17.

8. Imai, Y. \& Kuwatsuka, S., Metabolic pathways of the herbicide molinate in four strains of isolated soil microorganisms. Nihon Noyaku Gakkaishi (J. Pestic. Sci.), 11 (1986) 245-51.

9. Soderquist, C. J., Bowers, J. B. \& Crosby, D. G., Dissipation of molinate in a rice field. J. Agric. Food Chem., 25 (1977) 940-5.

10. Ross, L. J. \& Sava, R. J., Fate of thiobencarb and molinate in rice fields. J. Environ. Qual., 15 (1986) 220-4.

11. Imai, Y. \& Kuwatsuka, S., Residues of the herbicide molinate and its degradation products in pot soil and rice plants. Nihon Noyaku Gakkaishi (J. Pestic. Sci.), 13 (1988) 247-52.

12. Wang, Y. S., Jaw, C. G. \& Chen, Y. L., Uptake and metabolism of isouron in rice (Oryza sativa L.) seedlings. Biol. Fertil. Soils, 14 (1992) 1-4.

13. Murashiage, T. \& Skoog, F., A revised medium for rapid growth and bioassays with tobacco tissue cultures. Physiol. Plant., 15 (1962) 473-97.

14. Wang, Y. S., Hwang, K. L. \& Chen, Y. L., Absorption, translocation and metabolism of the herbicide naproanilide in tobacco. Pestic. Sci., 42 (1994) 53-8.

15. Casida, J. E., Gray, R. A. \& Tilles, H., Thiocarbamate sulfoxides: Potent, selective and biodegradable herbicides. Science (Washington), 184 (1974) 573-4.

16. Lay, M. M. \& Casida, J. E., Dichloroacetamide antidotes enhance thiocarbamate sulfoxide detoxification by elevating corn root glutathione content and glutathione $s$ transferase activity. Pestic. Biochem. Physiol., 6 (1976) $442-56$.

17. Schuphan, I. \& Casida, J. E., S-Chloroallyl thiocarbamate herbicides: Chemical and biological formation and rearrangement of diallate and triallate sulfoxides. J. Agric. Food Chem., 27 (1979) 1060-6.

18. Jablonkai, I. \& Hatzios, K. K., Microsomal oxidation of the herbicide EPTC and acetochlor and of the safener MG-191 in maize. Pestic. Biochem. Physiol., 48 (1994) 98-109. 